\title{
Response of NPK and Neem Cake on Soil Properties, Growth and Yield of Cluster Bean (Cymopsis tetragonoloba L.) Var-Laxmi-50
}

\author{
Manish Kumar Yadav , Tarence Thomas and P. Smriti Rao
}

Department of Soil Science and Agricultural Chemistry, Naini Agricultural Institute, Sam Higginbottom University of Agriculture, Technology and Sciences, Prayagraj - 211 007, U.P., India

*Corresponding author

\begin{tabular}{|c|c|}
\hline & A B S T R A C T \\
\hline & \multirow{4}{*}{$\begin{array}{l}\text { A field study was conducted on the "Response of NPK and Neem Cake on Soil properties, } \\
\text { Growth and yield of Cluster bean (Cymopsis tetragonoloba L.) Var-Laxmi-50" at the Soil } \\
\text { Science \& Agricultural Chemistry Research Farm, Sam Higginbottom University of } \\
\text { Agriculture, Technology and Sciences, Prayagraj during Kharif season } 2018 \text {. The soil of } \\
\text { experimental area falls in order Inceptisol and soil texture was sandy loam. treatment was } \\
\left.\text { T8L2N2 (@ N20P40K40 NPK kg ha }+5 \mathrm{q} \text { Neem Cake ha }{ }^{-1}\right) \text { organic carbon } 0.76 \% \text {, } \\
\text { available nitrogen } 324.26 \mathrm{~kg} \mathrm{ha}^{-1} \text {, available phosphorus } 32.93 \mathrm{~kg} \mathrm{ha}^{-1} \text { and available } \\
\text { potassium } 203.03 \mathrm{~kg} \mathrm{ha}^{-1}, \mathrm{pore} \text { space }(\%) 49.87 \text {, bulk density } 1.067\left(\mathrm{Mg} \mathrm{m}^{-3}\right) \text { and particle } \\
\left.\text { density } 2.612\left(\mathrm{Mg} \mathrm{m}^{-3}\right), \mathrm{pH} 6.78, \mathrm{EC} \text { at } 250 \mathrm{C}(\mathrm{dS} \mathrm{m})^{-1}\right) 0.23 \text { as compared to T0 L0N0 } \\
\text { (control). }\end{array}$} \\
\hline $\begin{array}{l}\text { Cluster bean, NPK, } \\
\text { Neem cake, } \\
\text { Physical, Chemical } \\
\text { properties of soil }\end{array}$ & \\
\hline Article Info & \\
\hline $\begin{array}{l}\text { Accepted: } \\
\text { 15 April } 2019 \\
\text { Available Online: } \\
10 \text { May } 2019\end{array}$ & \\
\hline
\end{tabular}

\section{Introduction}

Cluster bean [Cyamopsis tetragonoloba (L.) Taub] popularly known as "Guar" is an important legume crop mainly grown under rainfed condition in arid and semi-regions of Rajasthan during kharif season. It is very hardy and drought tolerant crop. Its deep penetrating roots enable the plant to utilize available moisture more efficiently and thus offer better scope for rainfed cropping. The crop also survives even at moderate salinity and alkalinity conditions. There is no other legume crop so hardy and drought tolerant as cluster bean (Kherawat et al., 2013).
Among dry land crops, guar occupies an important place in the national economy because of its industrial importance mainly due to the presence of gum in its endosperm (35 to $40 \%$ ). Cluster bean is grown for different purposes from very ancient time viz., vegetable, green fodder, manure and feed. It provides nutritional concentrate and fodder for cattle and adds to the fertility of soil by fixing considerable amount of atmospheric nitrogen. Cluster bean seed is used as a concentrate for animal and for extraction of "gum". Seed of cluster bean contain 28 to $33 \%$ gum. Guar gum has its use in several industries viz., textiles, paper, 
petroleum, pharmaceuticals, food processing cosmetics, mining explosives, oil drilling etc. Cluster bean is a leguminous crop and can fix $37-196 \mathrm{~kg} \mathrm{~N} \mathrm{ha}^{-1}$ year $^{-1}$.

In India, cluster bean is mostly grown in Rajasthan, Haryana, Punjab, Uttar Pradesh and Madhya Pradesh. Rajasthan occupies first position in India both in area and production. It accounts for almost $82.1 \%$ area and $70 \%$ production in India. Haryana and Gujarat has second and third position respectively. Rajasthan has an area of 30 lakh ha, production of 15.46 lakh tonnes with a productivity of $515 \mathrm{~kg} \mathrm{ha}^{-1}$. Rajasthan guar is mainly grown in Barmer, Churu, Sri ganganagar, Nagaur, Jalore, Sikar, Jaisalmer, Bikaner, Jaipur, Jhunjhunu and Alwar districts (Anonymous 2010-11).

The pods of cluster bean are as rich in food value as that of French bean. The composition of cluster bean is $81.0(\mathrm{~g})$ moisture, $10.8(\mathrm{~g})$ carbohydrate, $3.2(\mathrm{~g})$ protein, $1.4(\mathrm{~g})$ of fat, $1.4(\mathrm{~g})$ of minerals, $0.09(\mathrm{mg})$ thiamine, 0.03 (mg) riboflavin, 47 I.U. vitamin C, 316 I.U, vitamin $\mathrm{A}\left(100 \mathrm{~g}^{-1}\right)$ of edible portion).

Nitrogen: also plays an important role in synthesis of chlorophyll and amino acid, which contributes to the building units of protein and thus the growth of plants. Insufficient nitrogen may reduce yield drastically and deteriorates the quality of produce. Cluster bean being a legume crop which has the capacity to fix atmospheric nitrogen by its effective root nodules the major part of nitrogen is met through rhizobium present in the root nodules hence, crop does not require additional nitrogen for its initial growth and development stage. The nitrogen application increased crude protein, crude fibre contents, ash percentage, carbohydrates, leaf area per plant, dry matter and green fodder yield of cluster bean cultivars (Ayub et al., 2010).
Phosphorus: The phosphorus is the second important plant nutrients. An application of phosphorus influences symbiotic nitrogen fixation yield and quality of cluster pods.

Potassium: The potassium activates more than 60 enzymes and enzymatically catalyzes the system involved in photosynthesis, metabolism and translocation of carbohydrates and proteins, membrane permeability, stomatal regulation and water utilization. Other benefits ascribed to $\mathrm{K}$ include resistance of plants against pests, disease and stresses caused by drought, frost, salinity, sodicity and in assuring improved crop quality characteristics (Kherawat et al., 2013).

\section{Neem cake}

Neem cake known as non edible oil cake organic manure. The composition of Neem cake is $5.2 \% \mathrm{~N}, 1.0 \% \mathrm{P}, 1.4 \% \mathrm{~K}$. Neem cake also act as a nematocide. Neem cake act as a nitrogen inhibitor means reduce the nitrification. It supplies the available nitrogen for a long time in the soil. Katyayan, A. (2012).

\section{Materials and Methods}

The investigation on "Response of NPK and Neem Cake on Soil properties, Growth and yield of Cluster bean (Cymopsis tetragonoloba L.) Var-Laxmi-50" was carried out at the Dept. of Soil Science Research Farm, of Sam Higginbottom University of Agriculture, Technology and Sciences, Prayagraj duration kharif season 2018. The details of experiments site, soil and climate is described in this chapter together with the experimental design, layout plan, cultural practice, particulars of treatments, planting material and techniques employed for the parameters 
It is situated at $25^{\circ} 24^{\prime} 23^{\prime \prime} \mathrm{N}$ latitude, $81^{0} 50$ ' $38^{\prime \prime}$ Elongitude and at the altitude of 98 meter above the sea level. The area of Prayagraj district comes under subtropical belt in the South east of Uttar Pradesh, which experience extremely hot summer and fairly cold winter. The maximum temperature of the location reaches up to $46^{\circ} \mathrm{C}-48^{\circ} \mathrm{C}$ and seldom falls as low as $4^{0} \mathrm{C}-5^{0} \mathrm{C}$. The relative humidity ranged between 20 to 94 percent. The average rainfall in this area is around $1100 \mathrm{~mm}$ annually.

Experiment will be laid out in $3 \times 3$ factorial randomized block design with three levels of NPK and Neem cake plot size was $2 \times 2 \mathrm{~m}^{2}$ for crop seed rate is $15-20 \mathrm{~kg} \mathrm{ha}^{-1}$ (Cymopsis tetragonoloba L.) Var Luxmi-50.Cluster bean sowing was done on in 07-Aug-2018 and the source of NPK an Neem cake were Urea, SSP, MOP and Neem cake respectively. Dose of fertilizer was applied in respective plots according to treatment allocation uniform furrows opened by about $5 \mathrm{~cm}$. All the agronomic practices were carried out uniformly to raise the crop. The crop was harvested on November 2018.

\section{Results and Discussion}

\section{Bulk density $\left(\mathrm{Mg} \mathrm{m}^{-3}\right)$}

The data presented in shows the Bulk density $\left(\mathrm{Mgm}^{-3}\right)$ of soil as influenced by NPK and Neem cake seed inoculation. The response Bulk density $\left(\mathrm{Mgm}^{-3}\right)$ of soil was found to be non-significant in levels of NPK and Neem cake seed inoculation. The maximum Bulk density $\left(\mathrm{Mg} \mathrm{m}^{-3}\right)$ of soil was recorded 1.32 $\mathrm{Mg} \mathrm{m}{ }^{-3}$ in treatment $\mathrm{T}_{0}$ (control) and minimum Bulk density $\left(\mathrm{Mgm}^{-3}\right)$ of soil was recorded $1.06 \mathrm{Mgm}^{-3}$ in treatment $\mathrm{T}_{8}$ (@100\%NPK+100\% Neem cake). Similar results were also reported by Kumar et al., (2008), Reddy et al., (2005).

\section{Particle density $\left(\mathrm{Mg} \mathrm{m}^{-3}\right)$}

The data presented in shows the Particle density $\left(\mathrm{Mg} \mathrm{m}^{-3}\right)$ of soil as influenced by NPK and Neem cake seed inoculation. The response Particle density $\left(\mathrm{Mg} \mathrm{m}^{-3}\right)$ of soil was found to be non-significant in levels of NPK and Neem cake seed inoculation. The maximum Particle density $\left(\mathrm{Mg} \mathrm{m}^{-3}\right)$ of soil was recorded $2.61 \mathrm{Mg} \mathrm{m}^{-3}$ in treatment $\mathrm{T}_{8}$ (@100\%NPK+100\% Neem cake) and minimum Particle density $\left(\mathrm{Mg} \mathrm{m}^{-3}\right)$ of soil was recorded $2.26 \mathrm{Mg} \mathrm{m}^{-3}$ in treatment $\mathrm{T}_{0}$ (control). Similar results were also reported byKumar et al., (2008) and Reddy et al., (2005) (Table 1 and Fig. 1).

\section{Pore space (\%)}

The data presented in shows the \% Pore space of soil as influenced by NPK and Neem cake seed inoculation. The response of soil pore space was found to be significant in levels of NPK and Neem cake seed inoculation. The maximum soil pore space was recorded 49.87 $\%$ in treatment $\mathrm{T}_{8}$ (@100\%NPK+100\% Neem cake) and minimum soil pore space was recorded $45.66 \%$ in treatment $\mathrm{T}_{0}$ (Control). Similar results were also reported by Kumar et al., (2008) and Reddy et al., (2005).

\section{Soil pH (1:2) w/v}

The data presented in shows the $\mathrm{pH}$ of soil as influenced be NPK and Neem cake seed inoculation. The response of soil $\mathrm{pH}$ was found to be significant in levels of N P K and Neem cake seed inoculation. The maximum soil pH was recorded 7.33 in treatment $\mathrm{T}_{1}$ (@ $0 \%$ NPK @ +100\% Neem cake) and minimum soil pH was recorded 6.77 in treatment $\mathrm{T}_{8} \quad$ (@100\%NPK+100\% Neem cake). Similar results were also reported by Takase et al., (2011) and Cakmak et al., (2010). 


\section{$\mathbf{E C}\left(\mathbf{d S} \mathbf{m}^{-1}\right)$}

The data presented in shows the EC $\left(\mathrm{dS} \mathrm{m}^{-1}\right)$ of soil as influenced by NPK and Neem cake seed inoculation. The response of EC $\left(\mathrm{dS} \mathrm{m}^{-1}\right)$ of soil was found to be non-significant in levels of NPK and Neem cake seed inoculation. The maximum EC $\left(\mathrm{dS} \mathrm{m}^{-1}\right)$ of soil was recorded $0.234 \mathrm{dS} \mathrm{m}^{-1}$ in treatment $\mathrm{T}_{8}$ (@100\%NPK+100\% Neem cake) and minimum EC $\left(\mathrm{dS} \mathrm{m}^{-1}\right)$ of soil was recorded $0.187 \mathrm{dS} \mathrm{m}^{-1}$ in treatment $\mathrm{T}_{0}$ (control). Similar results were also reported by Takase et al., (2011).

\section{\% Organic carbon}

The data presented in shows the \% Organic carbon in soil as influenced by NPK and Neem cake seed inoculation. The \% Organic carbon in soil increased significantly with the increase in levels of NPK and Neem cake seed inoculation. The maximum \% Organic carbon in soil was recorded $0.76 \%$ in treatment $\mathrm{T}_{8} \quad(@ 100 \% \mathrm{NPK}+100 \% \quad$ Neem cake) which was significantly higher than any other treatment combination and the minimum \% Organic carbon in soil was recorded $0.48 \%$ in treatment $\mathrm{T}_{0}$ (control). Legumes have potential to improve soil nutrients status through biological nitrogen fixation and incorporation of biomass in to the soil as green manure. Similar findings were recorded by Kumar et al., (2008) (Table 1 and Fig. 2).

\section{Available nitrogen $\left(\mathrm{Kg} \mathrm{ha}^{-1}\right)$}

The data presented in shows the available Nitrogen in soil as influenced by NPK and Neem cake seed inoculation. The available Nitrogen in soil increased significantly with the increase in levels of NPK and Neem cake seed inoculation. The maximum available Nitrogen in soil was recorded 324.26 $\left(\mathrm{Kg} \quad \mathrm{ha}^{-1}\right)$ in treatment $\mathrm{T}_{8}$ (@100\%NPK+100\% Neem cake) which was significantly higher than any other treatment combination and the minimum available Nitrogen in soil was recorded 251.86 $\left(\mathrm{Kg} \mathrm{ha}^{-1}\right)$ in treatment $\mathrm{T}_{0}$ (control).Similar findings were also recorded by Mitra et al., (2006) and Banerjee et al., (2006).

Table.1 Response of NPK and neem cake on physical parameters of soil in cluster bean

\begin{tabular}{|c|c|c|c|}
\hline Treatment & $\begin{array}{l}\text { bulk density } \\
\left(\mathrm{Mgm}^{-3}\right)\end{array}$ & $\begin{array}{l}\text { Particle density } \\
\left(\mathrm{Mgm}^{-3}\right)\end{array}$ & Pore space $(\%)$ \\
\hline$T_{0}$ & 1.32 & 2.27 & 45.66 \\
\hline $\mathbf{T}_{1}$ & 1.16 & 2.35 & 46.00 \\
\hline $\mathbf{T}_{2}$ & 1.12 & 2.39 & 46.40 \\
\hline $\mathbf{T}_{3}$ & 1.11 & 2.44 & 46.90 \\
\hline $\mathbf{T}_{4}$ & 1.09 & 2.49 & 47.50 \\
\hline$T_{5}$ & 1.08 & 2.52 & 48.70 \\
\hline $\mathbf{T}_{6}$ & 1.07 & 2.57 & 49.01 \\
\hline $\mathbf{T}_{7}$ & 1.07 & 2.59 & 49.60 \\
\hline $\mathbf{T}_{8}$ & 1.06 & 2.62 & 49.87 \\
\hline F- test & NS & NS & $\mathbf{S}$ \\
\hline S. Em \pm & 0.008 & 0.05 & 0.044 \\
\hline C.D. $(\overline{\mathbf{P}}=0.05)$ & 0.0017 & 0.011 & 0.095 \\
\hline
\end{tabular}


Table. 2 Response of NPK and neem cake on chemical parameters of soil in cluster bean

\begin{tabular}{|c|c|c|c|c|c|c|}
\hline Treatment & $\begin{array}{c}\text { pH (1:2) } \\
\text { w/v }\end{array}$ & $\underset{\left(\mathbf{d S m}^{-1}\right)}{\mathbf{E C}}$ & $\begin{array}{c}\text { Organic } \\
\text { carbon } \\
(\%)\end{array}$ & $\begin{array}{l}\text { Nitrogen } \\
\left(K^{-1} \mathbf{~ h a}^{-1}\right)\end{array}$ & $\begin{array}{c}\text { Phospho } \\
\text { rus }(\mathrm{Kg} \\
\left.\text { ha }^{-1}\right)\end{array}$ & $\begin{array}{c}\text { Potassi } \\
\text { um }(\mathbf{K g} \\
\left.\text { ha }^{-1}\right)\end{array}$ \\
\hline $\mathbf{T}_{\mathbf{0}}$ & 7.33 & 0.187 & 0.48 & 251.86 & 21.10 & 128.10 \\
\hline$T_{1}$ & 6.96 & 0.187 & 0.54 & 284.16 & 22.56 & 136.40 \\
\hline $\mathbf{T}_{2}$ & 6.93 & 0.197 & 0.57 & 296.83 & 23.63 & 140.50 \\
\hline $\mathbf{T}_{3}$ & 6.90 & 0.213 & 0.60 & 298.76 & 24.60 & 144.73 \\
\hline $\mathbf{T}_{4}$ & 6.96 & 0.220 & 0.67 & 310.00 & 26.86 & 155.46 \\
\hline $\mathbf{T}_{5}$ & 6.83 & 0.227 & 0.71 & 313.83 & 28.06 & 164.10 \\
\hline $\mathbf{T}_{6}$ & 6.83 & 0.227 & 0.73 & 319.76 & 28.83 & 171.30 \\
\hline $\mathbf{T}_{7}$ & 6.86 & 0.237 & 0.74 & 321.43 & 31.56 & 185.10 \\
\hline $\mathbf{T}_{8}$ & 6.76 & 0.233 & 0.76 & 324.26 & 32.93 & 203.22 \\
\hline F- test & $\mathrm{S}$ & $\mathrm{S}$ & $\mathrm{S}$ & $\mathrm{S}$ & $\mathrm{S}$ & $\mathrm{S}$ \\
\hline S. Em \pm & 0.042 & 0.003 & 0.004 & 2.342 & 0.222 & 1.683 \\
\hline C.D. $(P=0.05)$ & 0.090 & 0.006 & 0.009 & 5.007 & 0.474 & 3.598 \\
\hline
\end{tabular}

Fig.1 Response of NPK and neem cake on physical parameters of soil in cluster bean

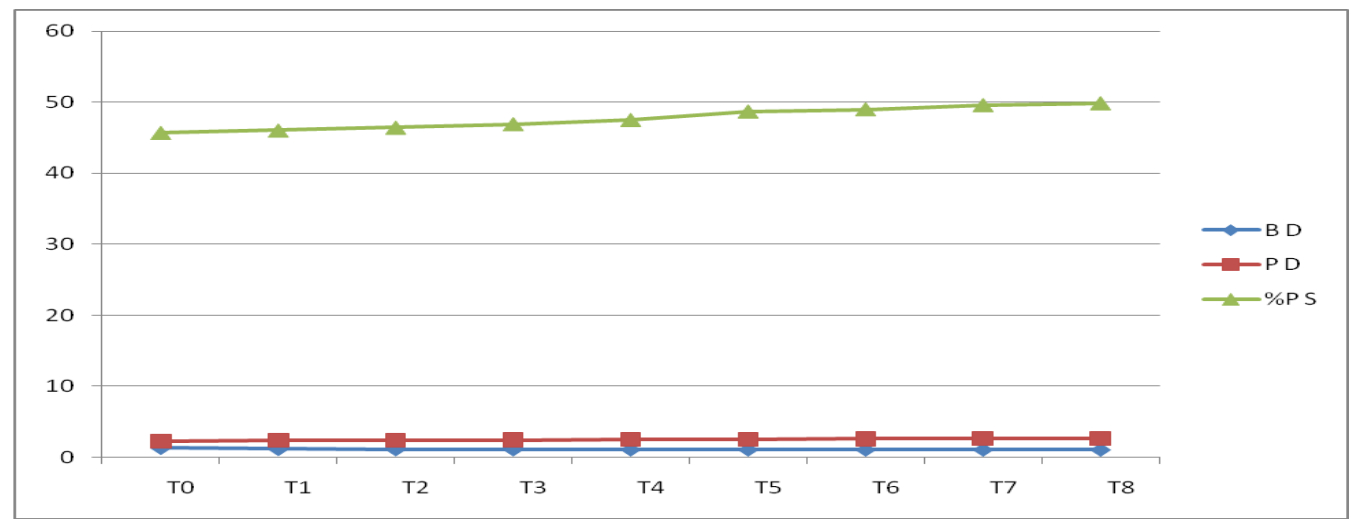

Fig.2 Response of NPK and neem cake on chemical parameters of soil in cluster bean

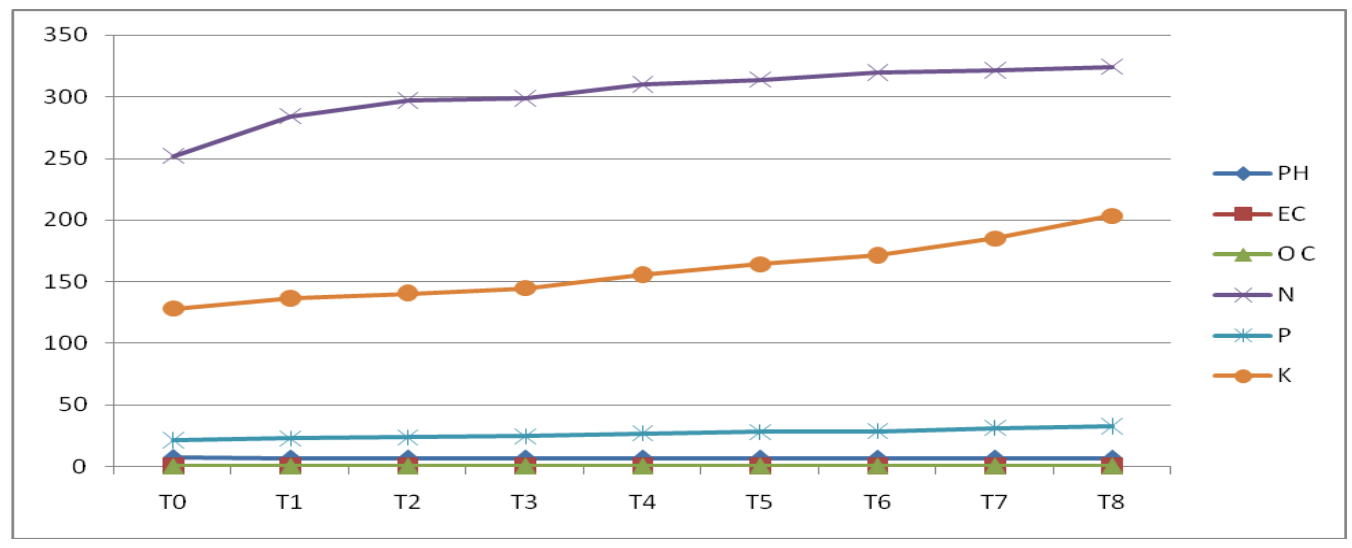




\section{Available phosphorus $\left(\mathrm{Kgha}^{-1}\right)$}

The data presented in shows the available Phosphorus in soil as influenced by NPK and Neem cake seed inoculation. The available Phosphorus in soil increased significantly with the increase in levels of NPK and Neem cake seed inoculation. The maximum available Phosphorus in soil was recorded $32.93\left(\mathrm{Kg} \mathrm{ha}^{-1}\right)$ in treatment $\mathrm{T}_{8}$ (@100\%NPK+100\% Neem cake) which was significantly higher than any other treatment combination and the minimum available Phosphorus in soil was recorded $21.10(\mathrm{Kg}$ $\mathrm{ha}^{-1}$ ) in treatment $\mathrm{T}_{0}$ (control). Similar findings were also recorded by Hussain et al., (2012).

\section{Available Potassium (Kgha ${ }^{-1}$ )}

The data presented shows the available Potassium in soil as influenced by NPK and Neem cake seed inoculation. The available Potassium in soil increased significantly with the increase in levels of NPK and Neem cake seed inoculation. The maximum available Potassium in soil was recorded 203.23 $\left(\mathrm{Kgha}^{-1}\right)$ in treatment $\mathrm{T}_{8}(@ 100 \% \mathrm{NPK}+100 \%$ Neem cake) which was significantly higher than any other treatment combination and the minimum available Potassium in soil was recorded $128.10\left(\mathrm{Kg} \mathrm{ha}^{-1}\right)$ in treatment $\mathrm{T}_{0}$ (control). Similar findings were also recorded by Beg et al., (2012).

Hence concluded, in the present investigation, it was apparent that application of NPK and Neem cake fertilizer in treatment $T_{8}(20 \mathrm{Kg}$ $\mathrm{N}, 40 \mathrm{Kg} \mathrm{P}, \mathrm{K} 40 \mathrm{Kg}$ and Neem cake $5 \mathrm{q} \mathrm{ha}^{-1}$ ) was found on physical and chemical parameters of soil such as bulk density, particle density, \% pore space, EC, $\mathrm{pH}$, Organic carbon, Available NPK than other treatment combinations. Bulk density, Particle density and EC are non-significant. Thus it can be concluded that different levels of NPK and Neem cake fertilizer improved soil available nutrient, increased soil available nitrogen, phosphorus, potassium and electrical conductivity. However, $\mathrm{pH}$ of soil decreased and also among the treatments $\mathrm{T}_{8}$ recorded the best treatment which increased the availability of nutrient and influenced on physical properties of soil as well.

\section{Acknowledgements}

The authors are grateful to the Vice Chancellor, Naini Agriculture Institute, SHUATS, Prayagraj for taking their keen interest and encouragement to carry out the research work

\section{References}

Anonymous (2010-11) Rajasthan Agriculture Statistics at a glance. Department of Agriculture Government of Rajasthan.

Ayub, M., Tahir, Nadeem, M. A., Zubair, M. A., Tariq, M., and Ibrahim, M. (2010) Effect of nitrogen applications on growth, forage yield and quality of three cluster bean varieties. Pak. j. life soc. Sci. 8 (2): 111-116.

Gireesh, S. P., and Malabasari, T. A. (2014) Effect of major nutrient and picking stage on seed yield and quality of cluster bean (Cyamopsis tetragonoloba L.).

Katyayan, A. (2012) Manures, fertilizers and biofertilizers, Fundamentals of agriculture. Kushal publications and distributors Varanasi.Vol.-1; p 231254.

Kherawat, B. S., Munna lal, Agarwal, M., Yadav, H. K. and Kumar, S. (2013) Effect of applied potassium and manganese on yield and uptake of nutrients by cluster bean (Cyamopsis tetragonoloba). Journal of Agricultural Physics 13 (1): 22-26.

Kumar, J., (2008) Physio-chemical properties 
of the soil, under the two forest plantation stands around Varanasi (U.P.), India.

Patel, C.S., Patel, J. B., Sathar, J. V. and Patel, P. M. (2006) Effect of integrated nutrient management on cluster bean (Cyamopsis tetragonoloba L.) seed production of cv. Pusa Nav Bahar. International Journal of Agricultural Research, 6:206-208.

Singh, B., and Kumar, R. (2016) Effect of integrated nutrient management on growth, yield and nutrient uptake of clusterbean (Cyamopsis tetragonoloba) under irrigated conditions. Agric. Sci. Digest., 36 (1) 2016: 35-39.

Takase, M., Sam-Amoah, Owusu, L. K. and Sekyere, J. D. (2011) The Effects Of Four Sources Of Irrigation Water On Soil Chemical And Physical Properties. Asian Journal of Plant Sciences 10: 1, pp 92-96.18.

\section{How to cite this article:}

Manish Kumar Yadav, Tarence Thomas and Smriti Rao, P. 2019. Response of NPK and Neem Cake on Soil Properties, Growth and Yield of Cluster Bean (Cymopsis tetragonoloba L.) VarLaxmi-50. Int.J.Curr.Microbiol.App.Sci. 8(05): 1752-1758.

doi: https://doi.org/10.20546/ijcmas.2019.805.202 